\title{
Report of Mollicutes in the Ear Canal of Domestic Dogs in Brazil
}

\author{
Sandra Batista dos Santos*, Maína de Souza Almeida, Luana Thamires Rapôso da Silva, \\ Júnior Mário Baltazar de Oliveira, Carlos Adriano de Santana Leal, \\ José Wilton Pinheiro Júnior, Rinaldo Aparecido Mota
}

\author{
Laboratory of Infectious Disease of Animals, Universidade Federal Rural de Pernambuco, Recife, Brazil \\ Email: *sanbsantos@gmail.com
}

Received 2 June 2016; accepted 8 July 2016; published 11 July 2016

Copyright (C) 2016 by authors and OALib.

This work is licensed under the Creative Commons Attribution International License (CC BY).

http://creativecommons.org/licenses/by/4.0/

(c) (i) Open Access

\begin{abstract}
Several microorganisms as bacteria, fungi, yeast and ectoparasites compose canine ear canal microbiota. These agents can be native or invasive pathogens that cause clinical otitis. The aim of this study was to associate Mollicutes in external ear canal with clinical otitis. 41 domestic dogs were examined, and a total of 82 otologic samples were collected using sterile swabs, placed in a plastic storage tube containing 2 milliliters of sterile phosphate buffer saline (PBS, pH 7.2) and appropriately labeled. The samples were processed for isolation of Mollicutes using Hayflick's medium. The frequency of Mollicutes class in the isolation was 32.9\% (27/82). 14.8\% (4/27) of the dogs, which were positive for Mollicutes, had external otitis and $85.2 \%(23 / 27)$ were healthy dogs. The genus Mycoplasma spp. was detected in $7.4 \%(2 / 27)$ by digitonin test. It was the first isolation of Mollicutes from the external ear canal in dogs. Although there have been important findings in this study, the presence of these bacteria cannot indicate the onset and perpetuation of external otitis in dogs.
\end{abstract}

\section{Keywords}

Mollicutes, Otites, Canines, Microbiota, Brazil

Subject Areas: Microbiology, Veterinary Medicine

\section{Introduction}

Microbiota of the ear canal in dogs is composed up of commensals and opportunists microorganisms. Bacteria of the genus Staphylococcus spp., Streptococcus spp. Corynebacterium spp., Proteus spp. are often found as a component of the normal flora of the ear canal, however unstable conditions may cause clinical otitis [1]. Identi-

\footnotetext{
${ }^{*}$ Corresponding author.
}

How to cite this paper: dos Santos, S.B., de Souza Almeida, M., da Silva, L.T.R., de Oliveira, J.M.B., de Santana Leal, C.A., Pinheiro Júnior, J.W. and Mota, R.A. (2016) Report of Mollicutes in the Ear Canal of Domestic Dogs in Brazil. Open Access Library Journal, 3: e2790. http://dx.doi.org/10.4236/oalib.1102790 
fied Staphylococcus intermedius, Staphylococcus aureus subsp. aureus, Pseudomonas spp., Proteus mirabillis and Klebsiella pneumoniae in dogs with severe otitis [2]. Many authors have described Staphylococcus spp. as the most common bacteria in otitis cases [2]-[6]. However, up to 35\% of the dog's clinical otitis isolation are Pseudomonas spp. and Gram-negative bacteria that not constitute the normal microbiota [7]-[9].

Mollicutes class is the smallest prokaryotes reported with replication capacity, and it is the most fastidious bacteria found in nature, that requires complex molecules such as cholesterol, sterol and urea for growth. These microorganisms are found in avian, human, insect, mammalian, plant and reptilian hosts. Some species are pathogenic and have been associated with different infections such as anemia, arthritis, otitis, infertility and respiratory disease [10]-[12]. Mycoplasmas in dogs has been described [13]. Nowadays, 15 species are known and two species with incompletely described. Species of mycoplasmas detected or isolated in dogs are: Acholeplasma laidlawii, Mycoplasma arginini, Mycoplasma bovigenitalium, Mycoplasma canis, Mycoplasma cynos, Mycoplasma edwardii, Mycoplasma feliminutum, Mycoplasma felis, Mycoplasma gateae, Mycoplasma haemocanis, Mycoplasma maculosum, Mycoplasma molare, Mycoplasma opalescens, Mycoplasma sp. HRC689, Mycoplasma sp. VJC358, Mycoplasma spumans and Ureaplasma canigenitalium [14] [15].

Some species detected in canine have been isolated in others hosts, though the canines' mycoplasma flora were not be fully described. This report refers to species that occur in the respiratory and reproductive tract, oral and nasal cavity, conjunctiva, pericardial sac, kidney, liver, lymph node, spleen, bladder, cerebral spinal fluid, blood, synovial membrane [16]-[19]. Several authors described canines' mycoplasmas species in different parts of the body [14] [19]. No previous studies of Mycoplasmas found the bacteria from the ear canal of dogs. The present study was conducted to investigate members of the Mollicutes class in the ear canal of canines with and without otitis.

\section{Material and Methods}

\subsection{Animals and Samples}

Domestic dogs from different localities attended veterinary hospital of the Federal Rural University-UFRPE, Recife-PE. 41 dogs at different ages and breeds, females and males were used in this study. Anamnesis, clinical examination and otoscopy were performed in the right and left sides the ear canal of each dog, in a total 82 samples collected. The otologic samples were collected with sterile swabs placed in a plastic storage tube containing 2 milliliters of sterile phosphate buffer saline (PBS, pH 7.2) and appropriately labeled. Furthermore, otologic swabs were collected for direct yeast examination. All samples were maintained at $4^{\circ} \mathrm{C}$ in a cooler with ice and forwarded to the Laboratory of Infectious Diseases of Animals (LDIC/DMV/UFRPE).

\subsection{Reagents Used for Isolation}

For isolation of Mollicutes the samples collected in phosphate buffer saline (PBS, pH 7.2) were cultivated in modified Hayflick's medium. Mollicutes isolates were confirmed by Dienes probe and Mycoplasma genus through a digitonin sensitivity test, according to [20].

\subsection{Procedures}

The Mollicutes isolation procedures consisted in the swabs were homogenized in the transport solution, and 100 $\mathrm{uL}$ was relocated to tubes containing $900 \mathrm{uL}$ of modified Hayflick's medium, and diluted up to $10^{-1}$ at $10^{-5}$ and spread in $2 \mathrm{~mL}$ and agar modified Hayflick's medium. All culture samples sowed were incubated at $37^{\circ} \mathrm{C}$ in $\mathrm{CO}_{2}$ incubator for at least 30 days, and blind peals were made for up to 60 days, before disposal of samples. The cultures were checked daily by using a stereomicroscopy $(40 \times)$ for the presence colonies.

\subsection{Statistical Analysis}

Associations between Mollicutes and external otitis were analysed by Fisher test, in the Software [21].

\section{Results}

A total frequency of Mollicutes in the isolation was 32.9\% (27/82). 14.8\% (4/27) of the dogs positive for Mollicutes were also external otitis and $85.2 \%$ (23/27) in dogs without clinical otitis (Table 1). The presence of 
Table 1. Mollicutes in domestic dogs in the metropolitan region from Recife-PE, Brazil.

\begin{tabular}{ccccccc}
\hline \multirow{2}{*}{ Mollicutes } & \multicolumn{2}{c}{ Positive otitis } & \multicolumn{2}{c}{ Negative otitis } & \multicolumn{2}{c}{ Total } \\
\cline { 2 - 7 } & $(\mathbf{A F})$ & $\mathbf{( R F} \%)$ & $(\mathbf{A F})$ & $\mathbf{( R F} \%)$ & $\mathbf{( A F )}$ & $\mathbf{( R F \% )}$ \\
\hline Positive & 4 & 14.8 & 23 & 85.2 & 27 & 100 \\
Negative & 2 & 100 & 0 & 0 & 2 & 100 \\
Total & 6 & & 23 & & 29 & 100 \\
\hline
\end{tabular}

$\mathrm{P}=0.036$. Absolut frequency (AF), Relative frequency (RF).

fried-egg colonies on solid medium and other appearance variations as raindrops were observed. In the digitonin senbility test 7.4\% (2/27) were positives, confirming presence Mycoplasma spp. genus. In the analysis of association of Mollicutes with otitis, this disease influenced negatively the isolation of Mollicutes in the ear canal of dogs, this association was significant $(\mathrm{P}=0.036)$.

\section{Discussion}

The etiology complex of the canines' otitis has been widely studied in worldwide. Although multiple factors are involved, the species richness of fungi, bacterias and ectoparasites can act as primary factors in clinical otitis in dogs [2]-[6] [22]. Mollicutes are fastidious for bacterial cultivation and few laboratories routinely cultivate these microrganisms, though culture is the most used method for detection of mycoplasmas in dogs [14] [17]. In the present study it was verified high frequency of Mollicutes in the ear canal of healthy dogs as compared to otitis, showing that possibly this bacteria is a component of the normal ear canal microbiota. In this study the dogs with otitis were identified other bacteria and yeasts in the ear canal.

The presence of other bacteria, fungi and yeasts in the ear canal of dogs can compete for nutrients creating undesirable conditions for mycoplasmas growth, since righ requirements and long-term isolation are needed. Several authors [16]-[19] [28]-[30] reported mycoplasmas in different sites of canine body, however in the ear canal there is no references list. The lack of studies may occur as result of greater relevance given to the association of other microorganisms as the main causes of otitis than mycoplasmas. Mycoplasmas have been found as a component of the microbiota of the ear canal in other animals species, such as cattle and goats, therefore it could be source of mycoplasmas for outbreak diseases (pneumonia, otitis, arthritis, mastitis) [23]-[26]. Mycoplasma cynos, which is frequently found in dogs respiratory disease, affects the upper respiratory tract. Mycoplasma edwardii, Mycoplasma spumans and Mycoplasma maculosum are usually found in the nasal cavity [11] [12] and Mycoplasma mucosicanis found in the oral cavity [15]. Furthermore clinical otitis caused by Malassezia, a common yeast found in dogs, acts as a limiting factor to the isolation of Mollicutes, by reason of Malassezia genus needs lipid and fatty acids for growth [27]. More studies are necessary to verify the relevance of Mollicutes in the ear canal of dogs and the role these bacteria in the etiopathogeny of otitis and other mycoplasmosis in dogs.

\section{Conclusion}

This is the first report of members of the Mollicutes class and Mycoplasma spp. in the ear canal of dogs however their association with clinical otitis cases remains unclear, and more studies are necessary for proving this relation.

\section{Acknowledgements}

For financial support of the CNPq (Post doctoral, Process No. 158980/2014-0 and Master Science).

\section{Conflicts of Interest}

The authors declare no conflicts of interest.

\section{References}

[1] Merchant, S.R. (2007) Microbiology of the Ear of the Dog and Cat. In: Gotthelf, L.N., Ed., Small Animal Ear Diseases: 
An Illustrated Guide, 2nd Edition, Saunders, Philadelphia, 188-200.

[2] Oliveira, L.C., Leite, C.A.L., Brilhante, R.S.N. and Carvalho, C.B.M. (2008) Comparative Study of the Microbial Profile from Bilateral Canine Otitis Externa. Canadian Veterinry Journal, 49, 785-788.

[3] Oliveira, L.C., Brilhante, R.S.N., Cunha, A.M.S. and Carvalho, C.B.M. (2006) Profile of Microorganisms Isolated from Dogs with Associated Media and Extern Otitis. Brazilian Journal of Veterinary and Animal Sciences, 58, 10091017.

[4] Sánchez, R.C., Calle, S.E., Falcón, N.P. and Pinto, C.J. (2011) Bacterial Isolation in Canine Ear Infections and Its Antimicrobial Susceptibility. Revista de Investigaciones Veterinárias del Perú, 22, 161-166.

[5] Scartezzini, M., Cordova, D.M., Lima, D.A., Silva, J.C.J. and Oliveira, S.J. (2011) Bacteriologic Diagnosis of Different Pathologies of Dogs and Cats, Antimicrobial Susceptibility Tests. Veterinary in Focus, 8, 152-157.

[6] Bugden, D.L. (2013) Identification and Antibiotic Susceptibility of Bacterial Isolates from Dogs with Otitis Externa in Australia. Australian Veterinary Journal, 91, 43-46. http://dx.doi.org/10.1111/avj.12007

[7] Scott, D.W., Miller, W.H., Griffin, C.E., Muller and Kirk (1996) Dermatologia de Pequenos Animais. 5 Edition, Rio de Janeiro, 1130.

[8] Nuttall, T. and Cole, L.K. (2007) Evidence-Based Veterinary Dermatology: A Systematic Review of Interventions for Treatment of Pseudomonas Otitis in Dogs. Veterinary Dermatology, 18, 69-77. http://dx.doi.org/10.1111/j.1365-3164.2007.00575.x

[9] Pye, C.C., Yu, A.A. and Weese, J.S. (2013) Evaluation of Biofilm Production by Pseudomonas aeruginosa from Canine Ears and the Impact of Biofilm on Antimicrobial Susceptibility in Vitro. Veterinary Dermatology, 24, 446-e99. http://dx.doi.org/10.1111/vde.12040

[10] Razin, S. and Tully, J.G. (1995) Methods and Diagnostic Procedures in Mycoplasmology. California, 29-31.

[11] Rycroft, A.N., Tsounakou, E. and Chalker, V. (2007) Serological Evidence of Mycoplasma cynos Infection in Canine Infectious Respiratory Disease. Veterinary Microbiology, 120, 358-362. http://dx.doi.org/10.1016/j.vetmic.2006.11.011

[12] Hong, S. and Kim, O. (2012) Molecular Identification of Mycoplasma cynos from Laboratory Beagle Dogs with Respiratory Disease. Laboratory Animal Research, 28, 61-66. http://dx.doi.org/10.5625/lar.2012.28.1.61

[13] Shoetensack, H.M. (1934) Pure Cultivation of Filterable Virus Isolatedfrom Canine Distemper. The Kitasato Archives of Experimental Medicine, 11, 227-290.

[14] Chalker, V.J. (2005) Canine Mycoplasmas. Research Veterinary Science, 79, 1-8. http://dx.doi.org/10.1016/j.rvsc.2004.10.002

[15] Spergser, J., Langer, S., Muck, S., Macher, K., Szostak, M., Rosengarten, R. and Busse, H.J. (2011) Mycoplasma mucosicanis sp. nov., Isolated from the Mucosa of Dogs. International Journal of Systematic Evololution Microbiology, 61, 716-721. http://dx.doi.org/10.1099/ijs.0.015750-0

[16] Rosendal, S. (1974) Canine Mycoplasmas II: Biochemical Characterization and Serological Identification. Acta Pathologica Microbiologica Scandinavica Section B: Microbiology and Immunology, 82, 25-32.

[17] Rosendal, S. (1975) Canine Mycoplasmas: Cultural and Biochemical Studies of Type and Reference Strains. Acta Pathologica Microbiologica Scandinavica Section B: Microbiology and Immunology, 83, 457-462.

[18] Rosendal, S. (1978) Canine Mycoplasmas: Pathogenicity of Mycoplasmas Associated with Distemper Pneumonia. The Journal of Infectious Diseases, 138, 203-210. http://dx.doi.org/10.1093/infdis/138.2.203

[19] Rosendal, S. (1982) Canine Mycoplasmas: Their Ecologic Niche and Role in Disease. Journal of the American Veterinary Medical Association, 15, 1212-1214.

[20] Whitford, H.W., Rosenbusch, R.F. and Lauerman, L.H. (1994) Mycoplasmosis in Animals: Laboratory Diagnosis. Iowa State University Press, Ames, 173.

[21] Center for Disease Control and Prevention (2012) EpiInfo ${ }^{\mathrm{TM}} 7$.

[22] Almeida, M.S., Santos, S.B., Mota, A.R., Silva, L.T.R., Silva, L.B.G. and Mota, R.A. (2016) Microbiological Isolation from the Ear Canal of Healthy Dogs and with Otitis Externa in the Metropolitan Region of Recife, Pernambuco. Pesquisa Veterinária Brasileira, 36, 29-32. http://dx.doi.org/10.1590/S0100-736X2016000100005

[23] DaMassa, A.J., Wakenell, P.S. and Brooks, D.L. (1992) Mycoplasmas of Goats and Sheep: Review Article. Journal of Veterinary Diagnostic Investigation, 4, 101-113. http://dx.doi.org/10.1177/104063879200400126

[24] Corrales, J.C., Esnal, A., De la Fe, C., Sánchez, A., Assunção, P., Poveda, J.B. and Contreras, A. (2007) Contagious Agalactia in Small Ruminants. Small Ruminant Research, 68, 154-166. http://dx.doi.org/10.1016/j.smallrumres.2006.09.010

[25] Santos, S.B., Nascimento, E.R., Faccini, J.L.H., Barreto, M.L. and Pereira, V.L.A. (2009) Potentially Pathogenic Mycoplasmas in the External Ear Canal of Clinically Normal Cattle in Southeast Brazil: First Report. Brazilian Journal of 
Microbiology, 40, 455-457. http://dx.doi.org/10.1590/S1517-83822009000300006

[26] Santos, S.B., Nascimento, E.R., Faccini, J.LH., Barreto, M.L. and Mota, R.A. (2012) Mycoplasmas Species Associated with the Ear Mites in Cattle. Pesquisa Veterinária Brasileira, 32, 293-296. http://dx.doi.org/10.1590/S0100-736X2012000400004

[27] Boekhout, T., Guého-Kellermann, E., Mayser, P. and Velegraki, A. (2010) Malassezia and the Skin: Science and Clinical Practice. Springer Science and Business Media, Berlin, 108-110.

[28] Edward, D.G. (1955) A Suggested Classification and Nomenclature for Organisms of the Pleuropneumonia Group. International Journal of Systematic and Evolutionary Microbiology, 5, 85-93. http://dx.doi.org/10.1099/0096266x-5-2-85

[29] Armstrong, D., Tully, J.G., Yu, B., Morton, V., Friedman, M.H. and Steger, L. (1970) Previously Uncharacterized Mycoplasma Isolates from an Investigation of Canine Pneumonia. Infection and Immunity, 1, 1-7.

[30] Adegboye, D.S. and Addo, P.B. (1978) Mycoplasmas from Vagina of a Bitch with Open Cervix Pyometra. Veterinary Record, 102, 62-63. http://dx.doi.org/10.1136/vr.102.3.62

\section{Warmly welcome your paper submission to OALib Journal!}

- Publication on a daily basis

- 9 subject areas of science, technology and medicine

- Fair and rigorous peer-review system

- Fast publication process

- Article promotion in various social networking sites (LinkedIn, Facebook, Twitter, etc.)

- Widely-targeted and multidisciplinary audience to read your research

Submit Your Paper Online: Click Here to Submit

Contact Us: service@oalib.com 